\title{
A New Contractile Protein of Squid Muscle A Comparative Study with Carp Actomyosin*
}

\author{
Juichiro J. Matsumoto \\ (Tokai Regional Fisheries Research Laboratory)
}

From investigation of the behaviors of the streaming birefringent protein in the aqueous extracts of the squid muscle and of the quantitative relationships between the said protein and some protein fractions in the squid muscle, an assumption was brought about that the observed streaming birefringence (SB) may be due to dissolving-out of the myosins** into the aqueous extracts ${ }^{1)}$. The assumption became more probable by comparing the intensity of SB of these fractions with each other'?

When the extract was dialysed against the solutions of various ionic strengths $(I)$, an amount of the streaming birefringent protein was found to precipitate at $I=0.3$ and $\mathrm{pH}$ $6.8^{3)}$. Thus, referring to the sofar described properties of muscle proteins of rabbit and carp ${ }^{455}$, the existence herein of actomyosin-like protein was assumed. On the basis of that fact the author succeeded in separating and concentrating the actomyosin-like protein. Then experimental bases were requested to decide if it is indeed identical with actomyosin.

For this purpose, methods are given such as electrophoresis, ultracentrifuge, or comparison of some physico-chemical properties of the protein, as $\operatorname{RoTH}^{6)}$ and $\mathrm{HAMOIR}^{7}$ ) did. They showed the respective identity of myosin and actomyosin of carp with those of rabbit which had been studied most profoundly. It was thought, however, more important to give attention upon their functional properties involved in the contraction of muscle, for these properties are the most specific ones to actomyosin.

For example, when adenosinetriphosphate (ATP) solution is added to actomyosin solution in $0.5 \sim 0.6 \mathrm{M} \mathrm{KCl}$, a sudden decrease of viscosity and $\mathrm{SB}$ (the first phase), a duration of the low viscosity or weak SB (the second phase), and a recovery (the third phase) are observed successively. As to the mechanism of these changes, researchers share the view as follows $\left.{ }^{4) 8}\right)$ 9) :

In the first phase, the shift to the right takes place in Equation (1) :

$$
\text { actomyosin } \stackrel{\text { ATP }}{\longrightarrow} \text { actin }+ \text { myosin }
$$

In the second phase, ATP is decomposed by the adenosinetriphosphatase (ATPase) activity of myosin or actomyosin as Equation (2) :

$$
\text { ATP }+\underset{\text { myosin or actomyosin (ATPase) }}{\longrightarrow}
$$

$\mathrm{ADP}+\mathrm{P}$

Received Feb. 16, 1957.

* Contribution B No. 259, from the Tokai Regional Fisheries Research Laboratory, Fisheries Agency.

Read before the Meeting of the Japanese Society of Scientific Fisheries on Oct. 28, 1955.

** The word "myosins" was used here to include both myosin or L-myosin and actomyosin. 
As soon as ATP is removed from the system, shift to the left in Equation (1) which results in the recovery of the viscosity and $\mathrm{SB}$ occurs.

Besides the above changes in solution, addition of ATP to the suspension of actomyosin gel in the media of lower ionic strengths $(I<0.15)$ causes a kind of syneresis called "superprecipitation"10). The ATPase activity to split ATP as Equation (2) is another functional property which is shared by both myosin and actomyosin.

In the present report, the ATP--response of SB, superprecipitation and some physicochemical properties of the concentrated streaming birefringent protein fraction of squid muscle are treated and compared with those of carp actomyosin and the existence of actomyosin in the said fraction is discussed.

\section{EXPERIMENTAL}

\section{METHODS}

Unless otherwise stated, methods employed are same to the previous report ${ }^{1)}$.

Samples Mantle muscle of both male and female of common squid, Ommastrephes sloani pacificus STEENSTRup, (body weight, $340 \sim 600$ g.) was used: Sample squids were purchased at wholesale markets. When they came to hand, they were very fresh and occa* sionally alive, being used in experiment as early as possible. Carps, Cyprinus carpio, including both sexes, were of weight $120 \sim 150 \mathrm{~g}$. : Extraction was done immediately after killed by cutting off the head, and using the dorsal lateral muscle.

Extraction To avoid the injurious effect of heavy metals ${ }^{30}$, glass-redistilled water was employed; metallic vessels and equipments were avoided; centrifuging tubes were covered with paraffin-paper during the centrifugation. The most part of the treatments including extraction, fractionation and centrifugation $(3,500 \sim 4,000$ r.p.m.) was done in a cold room $\left(0 \sim 8^{\circ} \mathrm{C}\right.$. $)$ and by using an ice-water bath. Thus the temperature of the liquid was not raised beyond $10^{\circ} \mathrm{C}$. even just after the centrifugation. The obtained sample solutions were kept in an ice-box.

Preparation of the squid protein The squid muscle was minced in a mortar and extracted repeatedly with cold water. From the extracts, ones which showed an intense SB were chosen and combined, added with $\mathrm{KCl}$ to $0.3 \mathrm{M}$ and dialysed overnight against 3 6 volumes of $0.3 \mathrm{M} \mathrm{KCl}$ in a cold place. When the dialysate was centrifuged, some amount of the precipitate was obtained which, by adding an equal volume of $1.2 \mathrm{M} \mathrm{KCl}$, becomes into an opalescent viscous solution showing an intense SB (Fig. 1). Table 1 shows the yield of protein in each fraction to the total muscle proteins. After the preparation was finished on the second day of the experiment, various tests were done whithin next 2 days using Fraction $S_{\tau}$. Dialysis against $0.3 \mathrm{M} \mathrm{KCl}$ as in the present work did not always give a good amount of the precipitate $P_{4}$ and a lower concentration of $\mathrm{KCl}$ such as $0.2 \mathrm{M}$ might be more favorable as will be reported later.

Preparation of actomyosin of carp muscle According to the method of SzENTGYÖRGYI ${ }^{10)}$ which was improved by WATANABE ${ }^{1112)}$, minced carp muscle was extracted with WEBER-EDSALL's solution ( $0.6 \mathrm{M} \mathrm{KCl}, 0.04 \mathrm{M} \mathrm{NaHCO}_{3}$, and $0.01 \mathrm{M} \mathrm{Na}_{2} \mathrm{CO}_{3}$ ) for 24 hours; after centrifuging-off the residual proteins, actomyosin was precipitated three 


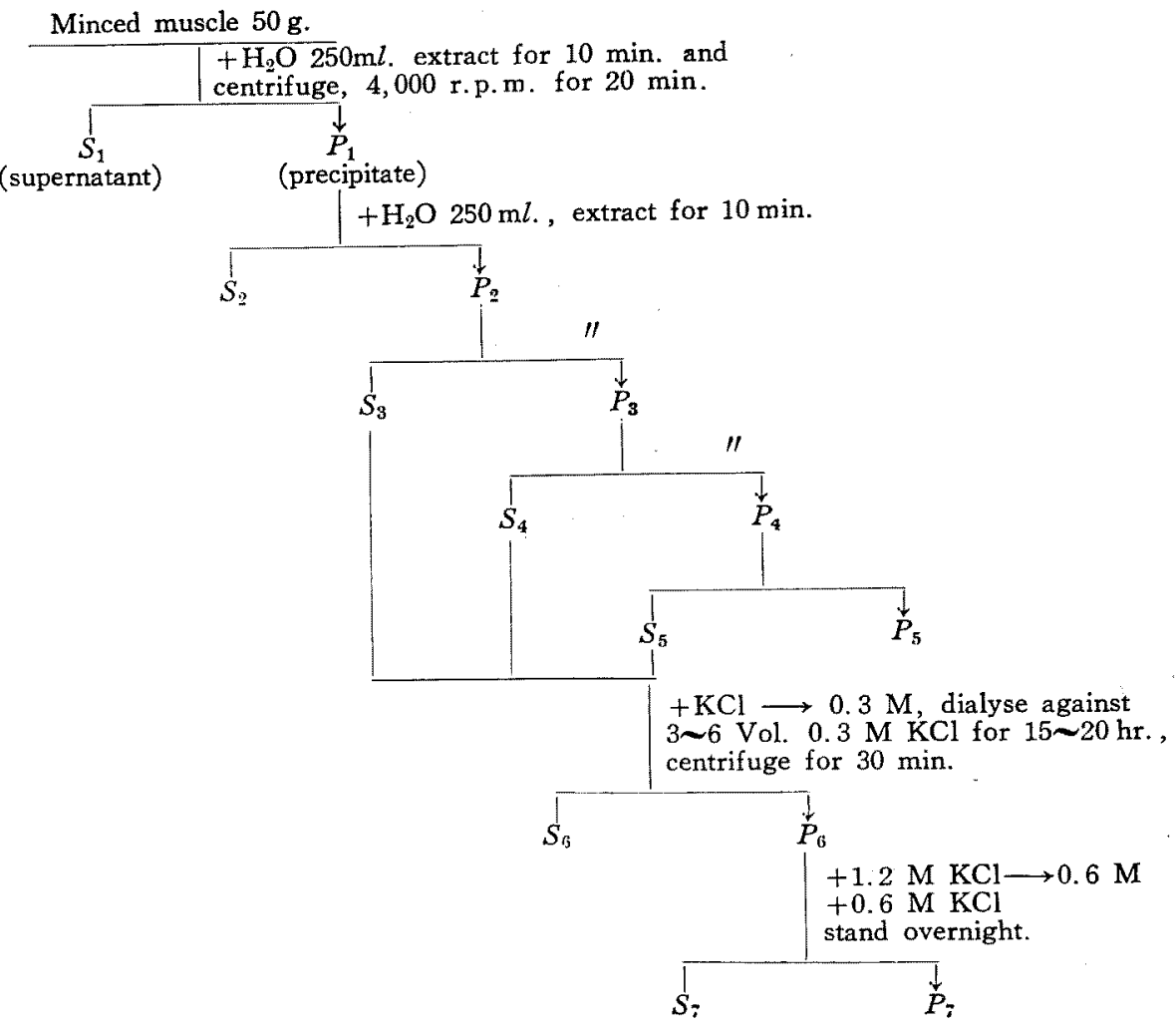

Fig. 1. Preparation of the streaming birefringent protein fraction in the aqueous extracts of squid muscle.

Table 1. A quantitaive aspect of the repeated extraction of squid muscle* with water

\begin{tabular}{|c|c|c|c|c|c|c|c|}
\hline \multirow{2}{*}{ Extract } & \multicolumn{2}{|c|}{ Volume $(\mathrm{m} l)}$. & \multirow{2}{*}{$\mathrm{pH}$} & \multirow{2}{*}{ SB } & \multirow{2}{*}{$\begin{array}{l}\text { Concentration } \\
\mathrm{mg} \text {. protein } / \mathrm{m} l \text {. }\end{array}$} & \multicolumn{2}{|c|}{ Yield } \\
\hline & Extract & Ppt. & & & & $\begin{array}{l}\text { mg. protein/ } \\
\text { g. muscle }\end{array}$ & $\begin{array}{c}\% \text { of total } \\
\text { protein }\end{array}$ \\
\hline$S_{1}$ & 227 & 66 & 6.1 & - & 3.66 & 16.6 & 11.2 \\
\hline$S_{2}$ & 172 & 88 & 6.2 & - & 1.79 & 6.2 & 4.2 \\
\hline$S_{3}$ & 167 & $116^{* *}$ & 6.3 & + & 1.62 & 5.4 & 3.7 \\
\hline$S_{4}$ & 134 & $165^{* *}$ & 6.5 & + & 2.27 & 6.1 & $4.2: 10.1$ \\
\hline$S_{5}$ & 125 & $193^{* *}$ & 6.8 & + & 1.27 & 3.2 & 2.2 \\
\hline$S_{7}^{* * *}$ & 56 & $1 * * * *$ & 6.7 & + & 4.42 & 6.1 & 4.2 \\
\hline
\end{tabular}

* 우 ; pH 6.1; total proteins, $14.8 \%$; Protein-N/total-N : 0.829 ; Sept. 26.

** These figures include the amount of the translucent paste described previously (C- and Dphases).

*** Concentrated fraction.

**** Probably denatured proteins.

times at $0.1 \sim 0.2 \mathrm{M} \mathrm{KCl}$, being washed twice with $0.05 \mathrm{M} \mathrm{KCl}$; the resultant white mass of the protein, which amounted to $26 \sim 29$ per cent of total muscle proteins, was dissolved into $0.6 \mathrm{M} \mathrm{KCl}$ solution. It showed an opalescent turbidity, a high viscosity and a marked $\mathrm{SB}$; the protein concentration, $12 \sim 62 \mathrm{mg} . / \mathrm{ml}$. $\mathrm{pH} 6.5 \sim 6.9$. 
Deternination of protein in solution Either semimicro-KJELDAHL method or biuret method $^{13)}$ was used. Nitrogen content in the proteins was conveniently assumed as 16.0 $\%$.

Streaming birefringence As reported by MigITA and MATSUMOTO"), a semiquantitative estimation was done using the instrument of OKADA and TADA ${ }^{14)}$. For, in this method, to classify the intensity of SB into 3 stages,,+ \pm , and - , was found more reliable than to classify into 4 stages,,,$+ \pm \doteq$, and - , as described in the previous report, the classification into 3 stages was adopted as the routine method, in place of the other. To detect the ATP-response of SB, protein concentration was adjusted to nearly the lowest level which showed + pattern of SB in a series of repeating two-fold dilutions of the sample solution with $0.6 \mathrm{M} \mathrm{KCl}$. To $8 \sim 10 \mathrm{~m} l$. of such protein solution, $0.5 \sim 0.8 \mathrm{ml}$. of $0.025 \sim 0.055 \mathrm{M} \mathrm{ATP}$ solution was added with or wthout the addition of $0.16 \sim 0.2 \mathrm{ml}$. of $\mathrm{M} / 20 \mathrm{MgCl}_{2}$, and $\mathrm{SB}$ was pursued.

Superprecipitation Protein solution was diluted with water to $I=0.1$, where the protein was lead to a turbid suspension. To $1 \sim 2 \mathrm{ml}$. of the suspension, different amounts of $0.025 \mathrm{M}$ ATP solution were mixed with or without adding $0.05 \mathrm{M} \mathrm{MgCl}_{2}$ of $1 / 50$ of its volume, the changes that follow during the storage at room temperature being observed and photographed.

ATP sample ATP-Na $\mathrm{Na}_{2}$ of National Biochemical Corporation and ATP-Na $\mathrm{N}_{4}$ of Zellstoffabrik were used. The purity estimated by $\Delta 7 \mathrm{P}$ was $72 \sim 100 \%$.

Salting-in range Phosphate buffer $(I=0.125, \mathrm{pH} 6.8) 2 \mathrm{ml}, \mathrm{KCl}$ solution of various concentrations $7 \mathrm{~m} l$, and protein solution in $0.5 \sim 0.6 \mathrm{M} \mathrm{KCl}$ solution $1 \mathrm{~m} l$. were mixed so that the resultant ionic strength of the mixtures varied from 0.05 to 0.5 and pH was kept near 6.8. After 2 hour cold storage, tubes were centrifuged (3,000 r.p.m., $20 \mathrm{~min}$.) and protein concentration was determined.

Isoelectric point $(\mathrm{p} l)$ The precipitation optimum was measured by the following method, where the ionic strength was kept at 0.4 and 0.6 by adding $\mathrm{KCl}$ solution to increase the solubility of the protein in the neighberhood of $\mathrm{p} l$. The mixtures were composed of acetate buffer of various $\mathrm{pH}$ values $(I=0.1) 2 \mathrm{ml}, 0.7 \mathrm{M} \mathrm{KCl} 2 \mathrm{ml}$, and protein solution (in $0.4 \mathrm{M} \mathrm{KCl}$ ) $4 \mathrm{ml}$.; after $1 \sim 2$ hour cold storage, the protein concentration and $\mathrm{pH}$ of the centrifuged solutions (3,000 r.p.m., 20 min.) were determined.

\section{RESULTS}

\section{(A) Response of SB to ATP}

ROTH $^{6)}$ and HAMOIR ${ }^{7)}$ have reported the decrease in viscosity of carp actomyosin upon adding ATP, but the whole course of the ATP-response of viscosity or SB of fish actomyosin has not yet been reported. Thus the change of $\mathrm{SB}$ of the carp actomyosin was studied both at $20^{\circ} \mathrm{C}$. and at $0^{\circ} \mathrm{C}$. At the room temperature, $\mathrm{SB}$ disappeared immediately after the addition of ATP and meanwhile it was found again (Fig. 2, Curves B and C.). These courses suggest that changes in Equations (1) and (2) have taken place there. As the ATPase activity of rabbit actomyosin which catalyzes the reaction in Equation (2), is inhibited by $\mathrm{Mg}$ ion at this ionic strength, Curves $\mathrm{D}$ and $\mathrm{E}$ of Fig. 2 show that there 


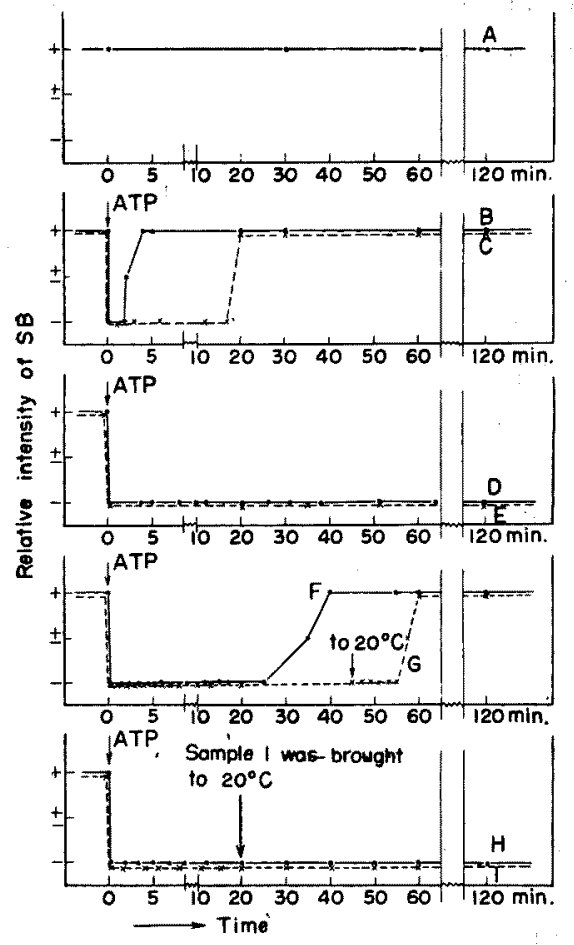

Fig. 2. Changes in $\mathrm{SB}$ of the actomyosin of carp muscle in $0.6 \mathrm{M} \mathrm{KCl}$ upon addition of ATP.

Date: Dec. $3 ; \mathrm{pH}$ of fresh muscle : 7.0 .

$\begin{array}{cccccc}\text { Curve } & \begin{array}{c}\text { Pretein concn. } \\ (\mathrm{mg} . / \mathrm{m} l .)\end{array} & \begin{array}{c}\mathrm{ATP} \\ (\mathrm{M})\end{array} & \begin{array}{c}\mathrm{MgCl}_{2} \\ (\mathrm{M})\end{array} & \mathrm{pH} & \begin{array}{c}\text { Temperature } \\ \left({ }^{\circ} \mathrm{C} .\right)\end{array} \\ \text { A } & 1.6 & - & - & 6.6 & 20 \\ \text { B } & 3.2 & 0.0012 & - & 6.6 & 20 \\ \text { C } & 1.6 & 0.0012 & - & 6.6 & 20 \\ \text { D } & 1.6 & 0.0012 & 0.001 & 6.8 & 20 \\ \text { E } & 1.6 & 0.0012 & 0.001 & 6.6 & 20 \\ \text { F } & 1.6 & 0.0012 & - & 6.8 & \sim 0^{*} \\ \text { G } & 1.5 & 0.0023 & - & 6.6 & \sim 0^{*} \rightarrow 20 \\ \text { H } & 1.6 & 0.0012 & 0.001 & 6.8 & \sim 0^{*} \\ \text { I } & 1.6 & 0.0012 & 0.001 & 6.8 & \sim 0^{*} \rightarrow 20\end{array}$

* The solution was occasionally taken out from the ice both for the observation of SB.

was working a similar effect also in the case of carp actomyosin. When ATP was added at $0^{\circ} \mathrm{C}$., Curves $\mathrm{F}$ and $\mathrm{G}$, where $\mathrm{Mg}$ ion was absent, resembled to Curves $\mathrm{B}$ and $\mathrm{C}$, but the second phase of Curve $F$ was longer and that of Curve $G$ did not finish until the mixture was brought to $20^{\circ} \mathrm{C}$. The fact suggests that the ATPase activity was depressed at the low temperature. When $\mathrm{Mg}$ ion was added (Curves $\mathrm{H}$ and $\mathrm{I}$ ), the once-disappeared SB did not restore as in the cases at room temperature (Curves B and C). The difference between Curves $B$ and $C$, which is shown in the duration of the second phase, might be due to that the protein concentration, and therefore the concentration of ATPase, was higher in Curve B than in Curve C. In the case of Curve G, SB which did not restore in the cold did reappear as soon as the reaction mixture was brought to the room temperature : In Curve G, more ATP was used than in Curve F. These results would 


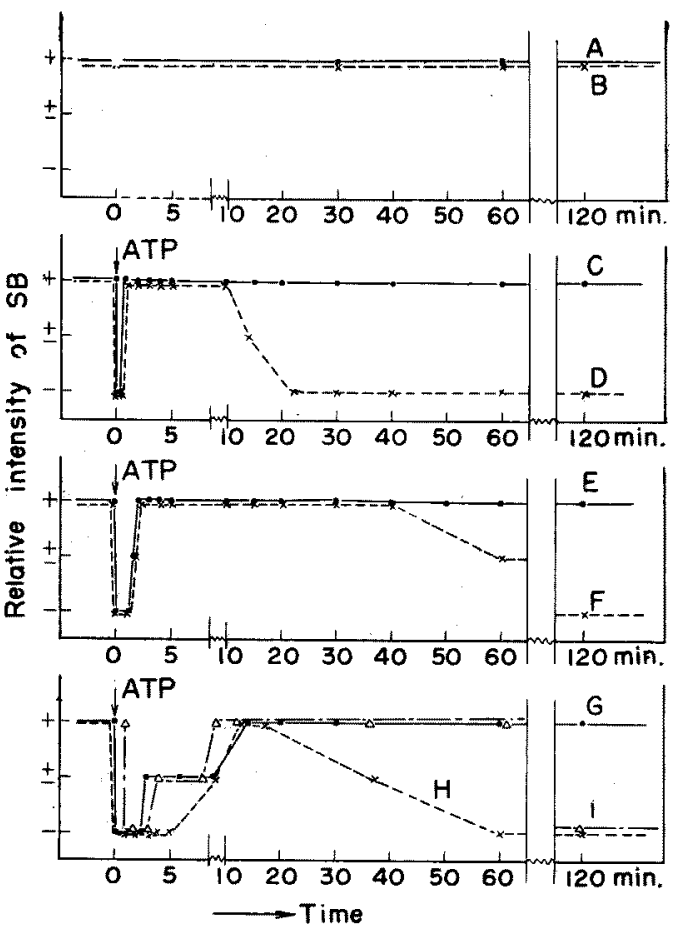

Fig. 3. Changes in $\mathrm{SB}$ of the streaming birefringent fraction in the aqueous extracts of squid muscle upon addition of ATP in $0.6 \mathrm{M} \mathrm{KCl}$.

Date : $A \sim F$, Sept. $1 ; G \sim I$, Sept. 27.

$\mathrm{pH}$ of fresh muscle : $\mathrm{A} \sim \mathrm{F}, 6.4 ; \mathrm{G} \sim \mathrm{I}, 6.1$.

$\begin{array}{cccccc}\text { Curve } & \begin{array}{c}\text { Protein concn. } \\ (\mathrm{mg} . / \mathrm{ml} l)\end{array} & \begin{array}{c}\mathrm{ATP} \\ (\mathrm{M})\end{array} & \begin{array}{c}\mathrm{MgCl}_{2} \\ (\mathrm{M})\end{array} & \mathrm{pH} & \begin{array}{c}\text { Temperature } \\ \left({ }^{\circ} \mathrm{C} .\right)\end{array} \\ \mathrm{A} & 2.1 & - & - & 6.6 & 24 \\ \mathrm{~B} & 2.1 & \overline{-} & - & 6.6 & \sim 0 \\ \mathrm{C} & 2.7 & 0.0012 & \overline{-} & 6.8 & 24 \\ \mathrm{D} & 2.7 & 0.0012 & 0.001 & 6.4 & 24 \\ \mathrm{E} & 2.7 & 0.0012 & \overline{0} & 6.7 & \sim 0^{*} \\ \mathrm{~F} & 2.7 & 0.0012 & 0.001 & 6.7 & \sim 0^{*} \\ \mathrm{G} & 2.0 & 0.0024 & \overline{-} & 6.2 & 23 \\ \mathrm{H} & 2.0 & 0.0024 & 0.001 & 6.2 & 23 \\ \mathrm{I} & 2.0 & 0.0024 & 0.001 & 6.2 & \sim 0^{*}\end{array}$

* The solution was occasionally taken out from the ice-bath for the observation of SB.

prove that carp actomyosin responds to ATP in a similar manner to rabbit actomyosin. It would be also shown that the method estimating SB by use of this apparatus deserves to treat the ATP-response of actomyosin.

With the streaming birefringent fraction of squid muscle obtained by the method of Fig. 1, the results were as shown in Fig. 3. As Curve $\mathrm{C}$ in the figure shows, the change in the absence of $\mathrm{Mg}$ ion gave the same course with the case of rabbit and carp actomyosin. Thus it is suggested that the streaming biref ringent fraction of squid muscle shows a similar $\mathrm{SB}$ response to ATP and also shows an ATPase activity. If the solution was ice-cooled, a change as Curve $\mathrm{E}$ was observed, wherein no difference was found except less quick recovery of $\mathrm{SB}$ than Curve $\mathrm{C}$ at the room temperature. The addition of $\mathrm{Mg}$ ion to the 
squid protein gave no appreciable effect as shown in Curves $\mathrm{D} ; \mathrm{F}, \mathrm{H}$, and $\mathrm{I}$, while $\mathrm{Mg}$ ion prevented the restoration of SB of carp actomyosin. Nevertheless, if SB was restored once, it resumed meantime to disappear which was not the case in the absence of $\mathrm{Mg}$ ion. Curves $G, H$ and I were obtained with another lot of sample solution. It might involve a difference in ATPase activity of both preparations, that SB restored after a longer period there than in Curves $\mathrm{C} \sim \mathrm{F}$.

In these experiments $38 \sim 150 \mathrm{~g}$. moles ATP per $10^{5} \mathrm{~g}$. carp actomyosin and $45 \sim 120 \mathrm{~g}$. moles per $10^{5} \mathrm{~g}$-squid protein were used.

\section{(B) Superprecipitation}

As to the superprecipitation of fish actomyosin, no observation has yet been reported. In the present study, the carp actomyosin showed a typical superprecipitation as shown in Fig. 4 and Table 2 : If ATP was added in the absence of $\mathrm{Mg}$ ion to the protein suspension which was obtained by diluting the original solution to 6 times of its volume and to $0.1 \mathrm{M} \mathrm{KCl}$ concentration, the protein aggregated immediately, the aggregate shrinking, and forming a stopper-like precipite within 3 minutes. When $0.001 \mathrm{M} \mathrm{Mg}$ ion was present, the turbidity of the protein suspension decreased just after the addition of ATP, and the protein gradually aggregated into a suspension of fine particles within 30 minutes, and separated from the mother liquid within 1 hour, forming a compact precipitate a night after, but it remained in a fine-particled state. While a stopper-like precipitate was formed in the room temperature and without $\mathrm{Mg}$ ion, a fine-particled superprecipitate was obtained even wtihout $\mathrm{Mg}$ ion, if cooled with ice. Thus the carp actomyosin was found to make super-

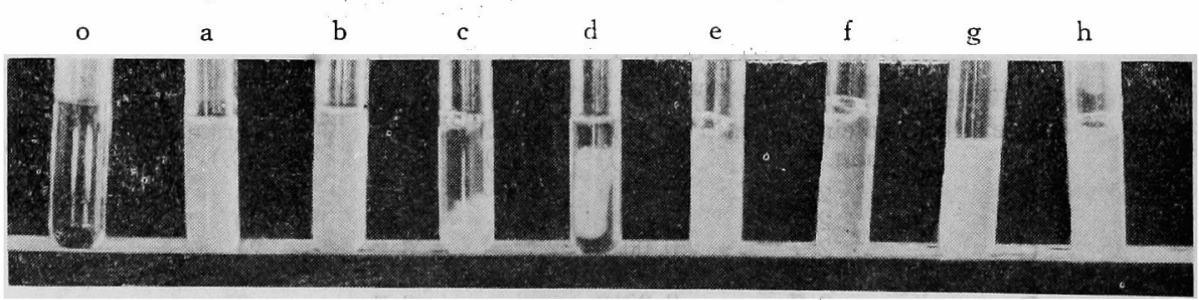

(A) Three min. after adding ATP.

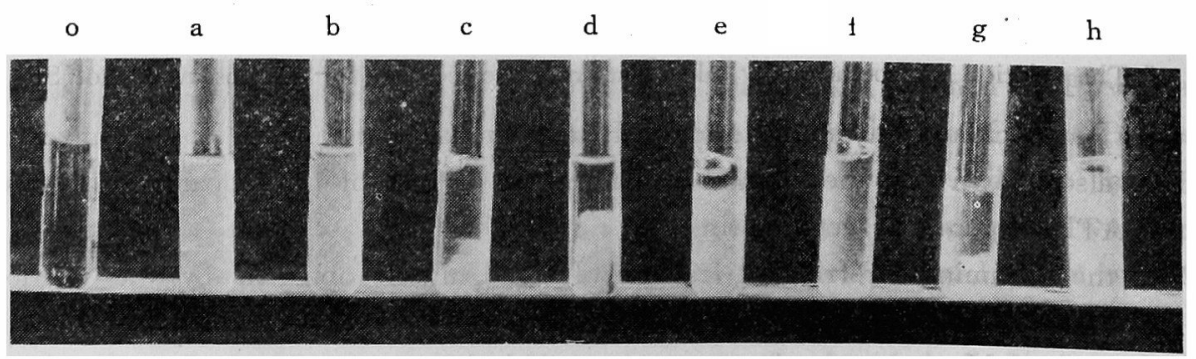

(B) Three hours after adding ATP.

Fig. 4. Superprecipitation of carp actomyosin.

Date : Dec. $3 ; \mathrm{pH}$ of fresh muscle : 7.0.

Tube o contains water as a control.

With tubes $\mathrm{a} \sim \mathrm{h}$ see Table 2 . 
Table 2. Superprecipitation of carp actomyosin

Date : Dec. $3 ; \mathrm{pH}$ of the mixtures : $\sim 6.8$.

\begin{tabular}{l|c|c|c|c|c|c|c|c}
\hline \hline & $\mathrm{a}$ & $\mathrm{b}$ & $\mathrm{c}$ & $\mathrm{d}$ & $\mathrm{e}$ & $\mathrm{f}$ & $\mathrm{g}$ & $\mathrm{h}$ \\
\hline $\begin{array}{c}\text { Protein concn. } \\
\text { (mg,/ml.) }\end{array}$ & 2.2 & 2.2 & 2.2 & 2.2 & 2.2 & 2.2 & 2.2 & 2.2 \\
$\mathrm{ATP}(\mathrm{M})$ & - & - & 0.005 & 0.00125 & 0.000125 & 0.005 & 0.00125 & 0.000125 \\
$\mathrm{MgCl}_{2}(\mathrm{M})$ & - & 0.001 & - & - & - & 0.001 & 0.001 & 0.001 \\
$\mathrm{KCl}(\mathrm{M})$ & 0.1 & 0.1 & 0.1 & 0.1 & 0.1 & 0.1 & 0.1 & 0.1 \\
\hline
\end{tabular}

(Observation after adding ATP)

\begin{tabular}{|c|c|c|c|c|c|}
\hline Immediately & \multirow[t]{5}{*}{ Turbid suspension } & Marked contraction & Clear su- & \multicolumn{2}{|c|}{ Becomes transparent } \\
\hline $10 \mathrm{~min}$. & & \multirow{2}{*}{$\begin{array}{l}\text { Contraction } \\
\text { proceeds }\end{array}$} & \multirow{2}{*}{$\begin{array}{l}\text { Stopper- } \\
\text { like ppt. }\end{array}$} & & \\
\hline $30 \mathrm{~min}$. & & & & \multirow{2}{*}{$\begin{array}{l}\text { Fine particled } \\
\text { ppt. aggregates }\end{array}$} & \multirow{2}{*}{$\begin{array}{l}\text { Fine- } \\
\text { particled } \\
\text { suspension }\end{array}$} \\
\hline $3 \mathrm{hr}$. & & \multirow{2}{*}{\multicolumn{2}{|c|}{ Stopper like ppt. }} & & \\
\hline $20 \mathrm{hr}$. & & & & \multicolumn{2}{|c|}{ Fine particled compact ppt. } \\
\hline
\end{tabular}

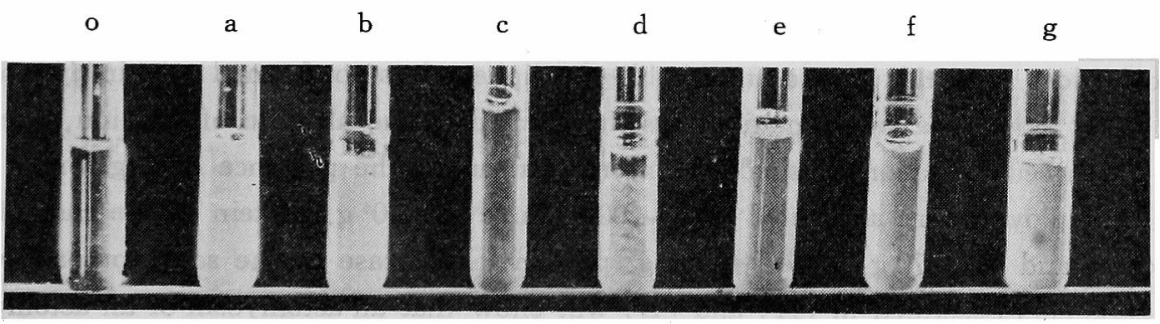

(A) Three min. after adding ATP.

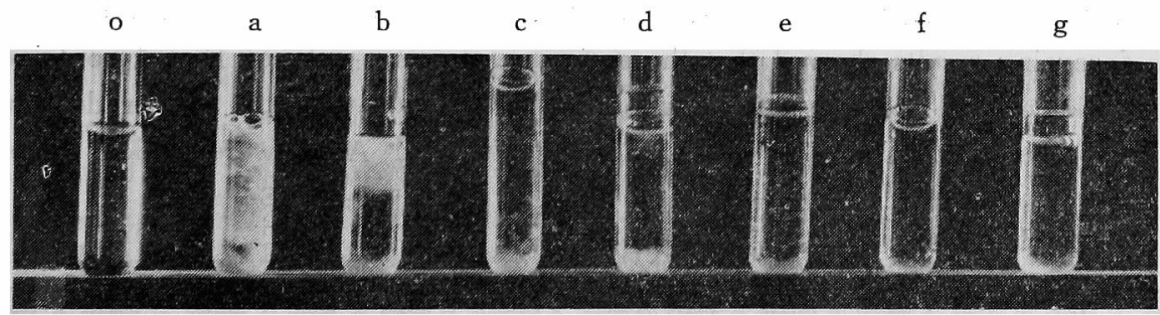

(B) sixteen hours after adding ATP.

Fig. 5. Superprecipitaion of the streaming birefringent fraction of the aqueous extracts of squid muscle.

Date : Sept. 26 ; $\mathrm{pH}$ of fresh muscle : 6.1.

Tude o contains water as a control.

With tubes a g see Table 3 .

precipitation similar to rabbit actomyosin in literatures ${ }^{10) *}$.

With the streaming birefringent fraction of squid muscle the results in Fig. ' 5 and

* In studying the superprecipitation, the author owed a detailed knowledge on the superprecipitation of rabbit actomyosin to the private communication of Prof. E. MiYazaki. 
Table 3. Superpretcipiteion of the streaming birefringent fraction in the aqueous extracts of squid muscle

\begin{tabular}{c|c|c|c|c|l|l|l}
\hline \hline & $\mathrm{a}$ & $\mathrm{b}$ & $\mathrm{c}$ & $\mathrm{d}$ & $\mathrm{e}$ & $\mathrm{f}$ & $\mathrm{g}$ \\
\hline $\begin{array}{c}\text { Protein concn. } \\
\text { (mg./ml.) }\end{array}$ & 0.74 & 0.74 & 0.74 & 0.74 & 0.74 & 0.74 & 0.74 \\
$\mathrm{ATP}(\mathrm{M})$ & - & - & 0.0042 & 0.00025 & 0.0042 & 0.0011 & 0.00024 \\
$\mathrm{MgCl}_{2}(\mathrm{M})$ & - & 0.001 & - & - & 0.001 & 0.001 & 0.001 \\
$\mathrm{KCl}(\mathrm{M})$ & 0.1 & 0.1 & 0.1 & 0.1 & 0.1 & 0.1 & 0.1 \\
\hline
\end{tabular}

(Observation after adding ATP)

\begin{tabular}{|c|c|c|c|c|c|c|}
\hline Immediately after & Turbid & suspension & & $\begin{array}{l}\text { Wool like } \\
\text { suspension }\end{array}$ & $\begin{array}{l}\text { Turbidity } \\
\text { decreases }\end{array}$ & $\begin{array}{c}\text { Turbid } \\
\text { Suspension }\end{array}$ \\
\hline $10 \mathrm{~min}$. & & & $\begin{array}{c}\text { Clear } \\
\text { supernatant } \\
\text { separates }\end{array}$ & $\begin{array}{l}\text { Pptn. } \\
\text { begins }\end{array}$ & \multirow{2}{*}{\multicolumn{2}{|c|}{ Suspension }} \\
\hline $60 \mathrm{~min}$. & & $\begin{array}{l}\text { Supernatant } \\
\text { separates }\end{array}$ & \multicolumn{2}{|c|}{ Ppt. sets down } & & \\
\hline $16 \mathrm{hr}$. & & $\begin{array}{c}\text { Voluminous } \\
\text { ppt. }\end{array}$ & \multicolumn{4}{|c|}{ Fine compact ppt. } \\
\hline
\end{tabular}

Tabe 3 were obtained, showing that the said fraction of squid does superprecipitate as carp actomyosin does. In this case a stopper-like precipitate was not formed even in the absence of $\mathrm{Mg}$ ion. While the sedimentation was more rapid in the absence of $\mathrm{Mg}$ ion, the precipitate when sedimentation finished was more compact in the presence of $\mathrm{Mg}$ ion.

ATP employed here amounted to $6 \sim 200 \mathrm{~g}$. mole per $10^{5} \mathrm{~g}$. protein in the case of carp actomyosin, and $33 \sim 570 \mathrm{~g}$. mole per $10^{5} \mathrm{~g}$. protein in the case of the squid preparation.

Experiments described in (A) and (B) will show that an actomyosin or an actomyosinlike protein is dissolved in the streaming birefringent fraction of squid.

\section{(C) Superprecipitation in the crude aqueous extracts of squid muscle}

The foregoing results showed that the aqueous extracts $S_{3} \sim S_{5}$ of Fig. 1 contained an actomyosin-like protein. A superprecipitation study was then tried on the crude aqueous extracts (Fig. 6). To extracts $S_{1} \sim S_{5}$ of Fig. 1, $\mathrm{KCl}$ and ATP were added to $0.1 \mathrm{M}$

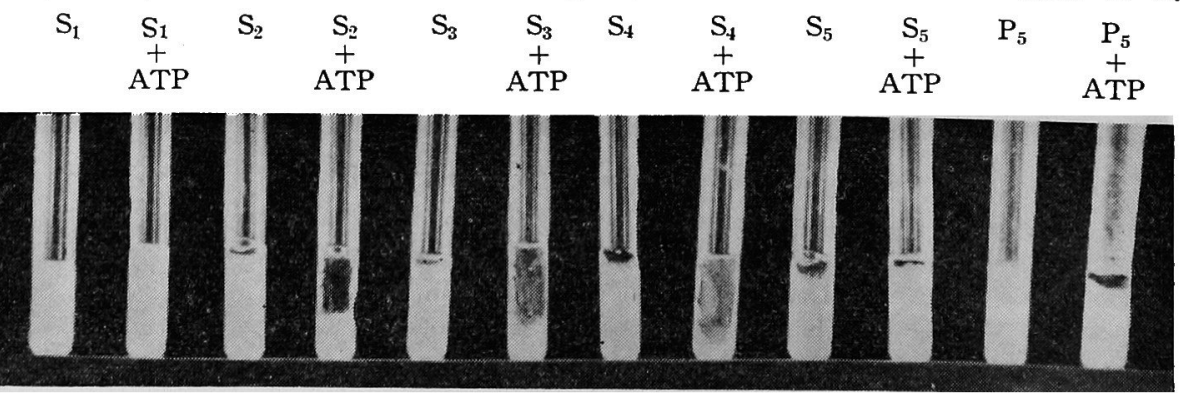

Fig. 6. Superprecipitation of the aqueous extracts of squid muscle. Picture 22 hours after adding ATP $(0.00092 \mathrm{M}) ; I=0.1(\mathrm{KCl})$; $\mathrm{pH} \sim 6.5$; Date : Sept. 26 ; $\mathrm{pH}$ of fresh muscle : 6.1.

$P_{5}$ is the fluent suspension covering the surface of the centrifuged residue of the fifth extraction. 
and $9.2 \times 10^{-4} \mathrm{M}$ respectively, and mixed. While, 10 minutes after mixing, only $S_{4}$ and $S_{5}$ showed separation of precipitate from the mother liquid, a night after, $S_{2} \sim S_{5}$ gave precipitates which were distinguishable from the controls. This suggested that an actomyosin-lik protein has been extracted as early as into $S_{2}$. Though, in $S_{5}$, the precipitate after sedimentation was less oompact than the control, the supernatant was more clear in the tube added with ATP, and it was suggested that a mild superprecipitation might occur also in $S_{5}$. The fluent suspension, $\mathrm{P}_{5}$, that covered the residue of the fifth extraction (D-phase of the previous report ${ }^{1}$ ) shrinked to a stopper-like precipitate upon addition of ATP.

\section{(D) Salting-in range and isoelectric point $(\mathrm{p} I)$}

To get further information, the salting-in range and $\mathrm{pI}$ were studied both on carp actomyosin and on the streaming birefringent fraction of squid.

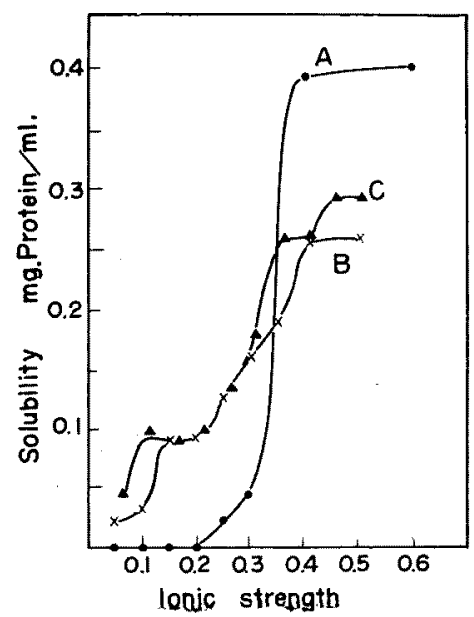

Fig. 7. The salting-in range of the carp actomyosin (Curve A) and the actomyosin-like fraction of squid muscle (Curves $B$ and $C^{*}$ ).

Date ; A, Dec. 3 ; B, June 23 ; C, Sept. 1.

$\mathrm{pH}$ of fresh muscle: $\mathrm{A}, 7.0 ; \mathrm{B}, 6.2 ; \mathrm{C}, 6.4$.

* The solution used in the experiment of $A \sim F$ in Fig. 3.

As shown by Curve A of Fig. 7, the carp actomyosin began to dissolve at $I=0.25$ and at $\mathrm{pH} \sim 6.8$, reaching a maximum solubility at $I=0.4$. Such behavior is in accordance with the results of RoTH and HAmorr, and the preparation treated here appears to be pure actomyosin.

The salting-in curve of the squid protein was as Curves $B$ and $C$ of Fig. 7: These curves suggest that, besides the major fraction which have the salting-in range at $I=0.25$ $\sim 0.4$, there is a minor fraction which is soluble at the ionic strength as low as 0.15 and occupies some $30 \%$ of the total protein in the solution. Thus the preparation is apparently not homogeneous. This point will be discussed later.

The $\mathrm{p} I$ of carp actomyosin was near $\mathrm{pH} 4.8 \sim 4.9$ at $I=0.4$ and near $\mathrm{pH} 4.2$ at $I=$ 0.6 , while that of the squid protein was found near $\mathrm{pH} 4.7$ at $I=0.4$ : There is no significant difference between $\mathrm{p} I$ values of carp actomyosin and of the squid protein.

The $\mathrm{p} I$ value found on carp actomyosin, however, seems rather lower than $\mathrm{p} I$ of 
actin-containing myosin of carp ( $\mathrm{pH} 5.1 \sim 5.4)$ reported by several investgators $\left.\left.{ }^{6) 15}\right)^{10}\right)$. But with myosin of rabbit, it was suggested that $\mathrm{p} I$ is dependent on the ionic strength ${ }^{17}$, and the present data were obtained at the higher ionic strengths. Thus, the problem of the $\mathrm{p} I$ would be dealt with after an additional study.

\section{DISCUSSION}

(1) From the above results, the streaming birefringent fraction of squid appears to be similar to rabbit or carp actomyosins, in two respects, the ATP-response of SB and the superprecipitation. For these properties reflect the most important characteristics of actomyosin, it would be reasonable to say that the streaming birefringent fraction studied here contains an amount of actomyosin or an actomyosin-like protein, which plays a role in the contraction of squid muscle in vivo, and also shows mechanochemical responses on addition of ATP in vitro.

Besides these similarlities, the contractile protein of squid differs in some respects from rabbit actomyosin. Firstly, it is extracted easily with water at a definite condition, being held in the extract even after centrifugation, but precipitated if $\mathrm{KCl}$ was added to the concentration of $0.05 \sim 0.3 \mathrm{M}$. Secondly, in the SB-response on adding ATP, the oncedisappeared $\mathrm{SB}$ did restore even in the presence of $\mathrm{Mg}$ ion, which is not the case with rabbit and carp actomyosins. Thus the ATPase activity of the actomyosin-like protein appears to be not inhibited by $\mathrm{Mg}$ ion. However, the protein preparation might be centaminated with "the water-soluble, Mg-activated ATPase ${ }^{18}$ "), for it was prepared according to an scheme (Fig. 1), which was designed in view of getting a good yield of the actomyosin-like protein, and not in view of making an enzymatically pure preparation.

Another difference was observed that, if ATP was once added together with $\mathrm{Mg}$ ion, the once-restored $\mathrm{SB}$ of the actomyosin-like protein of squid, resumed to disappear within 2 hours (Fig. 3, Curves D, F, H and I) : The once-restored $\mathrm{SB}$ was stable if $\mathrm{Mg}$ ion was absent (Fig. 3, Curves C, E, and G). The cause of this difference is obscure, but it might be a characteristic of the squid protein, because a similar course of the ATPresponse of viscosity was reported on myosin B extracted from the adductor of scallop ${ }^{19)}$ which is not so remote from squid in biological classification. However, result of YAGI et $a$ l. ${ }^{20)}$ should also be taken into account that myosin B fraction of scallop and other shellfishes appear similar to myosin B of rabbit in ATP response of viscosity, superprecipitation and in ATPase activity.

As shown in Fig. 5, the actomyosin-like protein did not make a stopper-like superprecipitate but a fine-particled one which was observed with carp actomyosin only in the presence of $\mathrm{Mg}$ ion. It might be due to that the test of the squid pretein was done at a lower protein concentration than that of carp actomyosin, or to that a small quantity of $\mathrm{Mg}$ ion was contained in the preparation of the actomyosin-like protein of squid.

(2) The salting-in curve of the fraction $S_{\text {; }}$ used in this work contained one or two minor fractionsas much as some $30 \%$ of the total proteins (Fig. 7, Curves B and C). Then a question arises which component will be responsible for the actomyosin-like properties. It seems most probable that the major component which begins salting-in at the ionic 
strength higher than 0.25 is it, as expected also from the salting-in behavior of rabbit or carp actomyosin. If a solution of the streaming-birefringent fraction of squid in $0.6 \mathrm{M} \mathrm{KCl}$ was stored in cold, the function to superpreciptate diminished day after day. In parallel to the diminution of this activity, the salting-in curve of the solution changed, suggesting that the major component is decreasing in amount while the minor ones are increasing ${ }^{21}$. This fact will favor the above view that the major component is the actomyosin-like protein.

(3) It is true that the actomyosin-like protein of squid showed functional characteristics of actomyosin as a contractile protein of muscle. However, it is also true that the protein has some properties deviating from actomyosins of rabbit or carp. Among these deviations a fact that the actomyosin-like protein is readily extracted from frech muscle with water is predominant. Since this property was found to be shared by the muscles of mollusks ${ }^{22)}$, the author proposes to call the protein tentatively by the name of "M-actomyosin" which means that there are some deviations from the properties of actomyosin of the striated muscles of rabbit and other animals.

\section{SUMMARY}

1) To prove the assumption that the streaming birefringence ( $\mathrm{SB}$ ) observed in the aqueous extracts of squid muscle is due to the dissolving-out of actomyosin or an actomyosin-like protein, the streaming birefringent protein was separated as a concentrated solution by precipitating it through dialysis against $0.3 \mathrm{M} \mathrm{KCl}$. Then the properties of the protein were compared experimentally with those of carp actomyosin.

2) Whereas SB of carp actomyosin, on addition of ATP, showed a very similar response to that reported on rabbit actomyosin (Fig. 2), the streaming birefringent protein of squid behaved itself in a similar but distinct way, if $\mathrm{Mg}$ ion was present (Fig. 3).

3) Both carp actomyosin and the streaming birefringent protein of squid showed a typical superprecipitation (Figs. 5 and 6 , Tables 2 and 3 ).

4) From salting-in curves, it was found that the used preparation of the streaming birefringent protein of squid contained one or two minor components, while that of carp actomyosin was homogeneous (Figs. 7).

5) It was inferred that, in the aqueous extracts of squid muscle, an amount of actomyosin-like protein is dissolved which has the functional properties of the contractile proteins. However, for some differences from actomyosins of rabbit and carp were found, and for these differences may be shared by mollusks, it was proposed to call this protein "M-actomyosin".

The author is indebted to Dr. M. Migita for his valuable advice, to Prof. S. MizuShima for tne encouragement to this work, and to Miss. A. Yamashita and Miss. M. AKIBA for their technical assistance.

\section{References}

1) Migtta, M. and Matsumoto, J. J. : Bull. Jap. Soc. Sci. Fish., 20, 641 52 (1954).

2) Mraita, M. and Matsumoto, J. J. : Read before the Annual Meeting of the Chemical Society of Japan on April 3, 1954. 
3) Matsomoto, J. J. : Bull. Jap. Soc. Sci. Fish. 23, 47〜52 (1957).

4) Weber, H. H. and Portzenl, H.: "Adv. Protein Chemistry", 7, 161 247 (1952).

5) Batlex, K. : "The Proteins", Vol. 2, Part B, Academic Press, New York (1954), p. 951 1055.

6) Rotr, E. : Biochem. Z., 318, 74 94 (1949).

7) Hamorr, G. : Bull. Soc; Chim. Biol. : 31, 118 22 (1949).

8) Engelfardt, V. A. : "Adv. Enzymology", 6, 147 91 (1947).

9) Mommaerts, W. F. H. M. : J. Gen. Physiol., 31, 361 75 (1948).

10) Szent-Györgyi, A. :Chemistry of Muscular Contraction", Academic Press, New York (1947).

11) Watanabe, S. : "Standard Methods of Biochemistry" (in Japanese), Bunkyudo, Tokyo, 1953, p, 245.

12) Mitazakt, E., Terayama, Y. and Yotazaka, Y.: Sapporo Medical J., 5, 209 12 (1952).

13) Matsumoto, J. J. and Kanamitsu, T. : Bull. Jap. Soc. Sci. Fish., 21, 284 8 (1955).

14) Okada, M. and TAda, S. : Bull. Jap. Soc. Sci. Fish., 20, 224 34 (1954).

15) Mort, T. and Asakawa, S. : Bull. Jap. Soc. Sci. Fish., 12, 62 72 (1943).

16) Suxama, M. : Bull. Jap. Soc. Sci. Fish., 15, 507〜14 (1948).

17) SarkaR, N. K. : Enzymologia, 14, 237 45 (1950).

18) Mommaerts, W. F. H. M. : "Muscular Contraction", Interscience Publisher, New York (19" 50) p. 96.

19) Yogoxama, M., Terayama, Y. and Nagal, T. : Kagaku, 22, 473 (1952).

20) Yagi, K., SaSaki, A. and Matsomtya, H. : J. Jap. Biochem. Soc., 26, 630 3 (1954).

21) Matsumoto, J. J. : Unpublished.

22) Migita, M., Matsumoto, J., Aoe, N. and Arai, T. : Read before the Meeting of the Jap. Soc. Sci. Fish. on Oct. 2, 1954. 